\title{
O LATIM NA COLONIZAÇÃO DO BRASIL QUINHENTISTA
}

Leonardo Kaltner

\begin{abstract}
RESUMO
No presente artigo, analisamos a história do uso e do ensino de Latim no contexto do Humanismo renascentista português e sua influência no Brasil quinhentista, como instrumento de colonização linguística para a América portuguesa. Para essa análise, selecionamos um excerto da obra novilatina De Gestis Mendi de Saa (Sobre os feitos de Mem de Sá), escrita no Brasil pelo missionário jesuíta José de Anchieta.
\end{abstract}

PALAVRAS-CHAVE: Estudos Culturais; Colonização Linguística; América Latina.



onstitui-se o século XVI em interessante capítulo da história das ideias linguísticas, seja pelo Humanismo renascentista europeu, com intensa atividade de pesquisa e publicaçóes, em tipografias e universidades, após o aperfeiçoamento da imprensa por Gutenberg ${ }^{1}$, seja pelas navegações e pelo contato intercultural entre povos e civilizaçóes diversas. Neste contexto, que envolve diversos atores políticos, está inserido o início do processo de colonização das Américas por reinos europeus absolutistas no século XVI. Para se analisar, em perspectiva pós-colonial, o processo de ocupação territorial, de que surgiu o Brasil no século XVI, um dos fatores centrais é a questão linguística, referente, sobretudo, ao contato linguístico inicial e à política de colonização linguística posterior:

1 REES, 2005, p. 90: "In the 45 years after Gutenberg perfected his printing press and printed the Bible, from 1455 to 1500 , more than 10 milions books were printed. By the year 1501, there were 1,120 print shops in 260 towns in 17 European countries". 
No processo colonizador, circulam essas imagens sobre as línguas, sobre essas línguas constitutivas de povos culturalmente distintos que se defrontam em condiçôes de produção tais que uma dessas línguas, chamada de língua colonizadora, visa impor-se sobre a(s) outra(s) colonizada(s). Isso rege, no devir do processo de colonização, a forma como vai sendo construída uma relação muito singular: o lugar de onde o colonizado fala se constitui no entremeio da heterogeneidade linguística inerente à colonização. Aquela que virá a ser a língua nacional se organiza justamente aí, nessa disputa por espaços de comunicação, em meio ao confronto entre políticas de sentidos das línguas em confronto/contato, ou seja, entre diferentes produçóes de sentidos e de práticas sócio-históricas que se encontram ligadas a cada língua específica (MARIANI, 2003, p. 74).

Constituíam-se os regna Brasillia do século XVI, territorialmente, de estreita faixa litorânea, concedida ao reino de Portugal pelo papado através da Bula Inter Coetera e do Tratado de Tordesilhas (1494), havendo apenas núcleos iniciais de colonização dispersos, conectados mais pela navegação do que por terra. Dessa forma, a colonização, que fora iniciada como empresa terceirizada, pelo falho regime de capitanias hereditárias, em 1534, logo se organizaria pela instituição de um governo-geral em 1548, tendo sua capital na cidade de Salvador (COSTA, 2011, p. 57). A grosso modo, o Estado brasileiro surgiu com a instituição do governo-geral, integrado ao modelo de Estado clássico absolutista português como colônia, subordinado ao papado, através da instituição do padroado.

Não só os portugueses e espanhóis, entre os europeus, ocuparam o território ao sul da América. Além de atos de pirataria constantes, houve a tentativa de colonização francesa do Rio de Janeiro entre 1555 e 1567, conhecida como França Antártica, custeada por Gaspar de Coligny e capitaneada por Villegagnon, cujos domínios se estendiam da Baía de Guanabara até Cabo Frio:

Em novembro de 1555, três navios franceses sob o comando por Nicolas Durand de Villegagnon, nobre cavaleiro da Ordem de Malta, chegaram à Baía da Guanabara com o intuito 
de fundar uma colônia. Havia muito que embarcações francesas navegavam por aquelas bandas, realizando o escambo com as populaçôes indígenas, embarcando para a Europa grandes quantidades de pau-brasil. O projeto de fundaçáo da França Antártica tinha o apoio de Henrique II, Rei de França, de Gaspar de Coligny, Almirante da Marinha Real, do Duque de Guise, cardeal de Lorena, e de comerciantes e armadores franceses. Um dos objetivos era garantir à França uma parcela do mercado de especiarias monopolizado pelos portugueses (BICALHO, 2008, p. 32).

O contexto de colonização linguística que se desenha no Brasil do século XVI é complexo, predominando documentos escritos nas línguas europeias modernas. Com base em observaçóes desses documentos, desenvolve-se uma leitura não só do contexto linguístico do Brasil do século XVI, mas também do processo de colonização linguística que se instituiu como política para o estabelecimento da colônia, a fim de efetivar a posse do território e iniciar a produção de açúcar.

A comunidade urbana e multicultural que formava o projeto de colonização no Brasil, em meados do século XVI, é estimada em cerca de $60 \mathrm{mil}$ habitantes, que vivam em três cidades, Salvador, São Paulo e Rio de Janeiro, e cerca de 14 vilas, entre as quais se destacavam Olinda e o porto de Recife (RIBEIRO, 2002, p. 194). Estima-se que, em fins do século XVI, a população total relacionada ao projeto colonial no Brasil seria composta de cerca de 50 mil "brancos da terra", em maioria mamelucos, havendo cerca de $30 \mathrm{mil}$ escravos africanos, cerca de 120 mil índios integrados ao projeto colonial, cristianizados sobretudo pelas missóes jesuíticas, e cerca de 4 milhôes de índios vivendo no que seria o território atual do Brasil, alheios ao projeto colonial predominantemente litorâneo, que se concentrava, inicialmente, no Nordeste (RIBEIRO, 2002, p. 151).

Esta comunidade linguística do século XVI comunicava-se em português e espanhol nas cidades e vilas litorâneas, nas feitorias e nas fortalezas, nos engenhos, utilizando o português para a escrita e administração. Estabelece-se o uso de uma língua de contato com os povos indígenas, após a chegada dos jesuítas, a língua-geral do século XVI, o Tupi da costa, normatizado pelos 
missionários através da gramática do Latim e utilizado nas missóes, predominando o Tupi também entre a população mameluca, que seria utilizado na expansão ao interior e aos sertôes, ao sul do Brasil, como em São Vicente (CÂMARA JÚNIOR, 1979, p. 101-102). Neste contexto, o Latim em uso serviria também ao contexto litúrgico, para a prática religiosa.

Com a fundação dos engenhos ${ }^{2}$, pelo transplante de povos africanos ao Brasil, na condição de escravos, surgem também os primeiros núcleos de resistência afro-brasileira, havendo o registro dos primeiros quilombos em 1573 (MOURA, 2004, p. 335). O grupamento linguístico africano predominante no Brasil do século XVI vinculava-se ao chamado ciclo da Guiné e às diversas etnias da Gâmbia ao Reino do Congo ${ }^{3}$ :

Num primeiro momento, do fim do século XV até por volta de 1560, o Reino do Congo desempenhou o papel essencial. A partir de 1529, os documentos de origem portuguesa indicam ter sido a regiáo do Pool Malebo um dos principais fornecedores de escravos, graças às rotas ligando-a a Mbanza Congo (São Salvador) e a Mpinda. Em meados do século XVI, os anziques (tio, teke do Pool) formavam importantes contingentes da população servil do Peru, da Colômbia e do Brasil. (OGOT, 2010, p. 635-636).

2 RIBEIRO, 2002, p. 150: “Celso Furtado (1959) calcula que funcionariam, então, 120 engenhos de açúcar, e que o rebanho bovino atingiria, já, 680 mil cabeças. A produção anual de açúcar teria alcançado 2 milhóes de arrobas, cujo valor seria de 2,5 milhóes de libras esterlinas daquele tempo. Como ele assinala, uma renda tão extraordinariamente alta fazia do empreendimento colonial português a empresa mais próspera da época. E, por isso mesmo, a mais cobiçada por holandeses e franceses, que passariam, desde então, a disputar sua posse".

3 OLIVEIRA, 1997, p. 39: "No início, para os portugueses, a Guiné teria se restringido ao litoral da costa ocidental africana, que tinha como centro comercial a feitoria de Cachéu, subordinada às ilhas de Cabo Verde. Esta era a área descrita nos contratos de arrendamento do século XV. Entretanto, à medida em que a expansão do comércio português avançou para o sul, o termo passou a ser também utilizado para designar as partes do litoral então conhecidas como Costa da Pimenta, Costa do Marfim, Costa do Ouro e Costa dos Escravos. Assim, toda a África Ocidental ao norte do Equador, do Rio Senegal ao Gabão, era conhecida então como a Guiné”. 
Neste contexto original da colônia, constituída para exploração pela metrópole, uma sociedade multicultural estava formando-se sob uma base pluriétnica, predominantemente de matriz lusa e tupi, com a ocupação dos espaços litorâneos do território, cujo principal desejo seria, posteriormente, o avanço ao sertão. Dessa forma, o Brasil do século XVI apresentava sua origem como colônia ultramarina, com a ocupação do território dividido em dois projetos coloniais europeus distintos, de um lado, a produção de açúcar, em engenhos, com mão-de-obra escrava da África, e, de outro, o projeto missionário de expansão do cristianismo entre a população indígena.

A ação missionária, como projeto colonial, foi intermediadora entre os povos indígenas e o colonizador europeu, pelo fato de que representava não só os interesses do papado na expansão da cristandade, mas também um vínculo à tradição universitária portuguesa quinhentista, integrante de um contexto cultural mais amplo, o Humanismo renascentista. Esta tradição, iniciada pela reforma da Universidade de Coimbra por D. João III, influenciaria profundamente a fundação de Colégios pelos missionários jesuítas no Brasil do século XVI, que funcionariam como centros irradiadores da filosofia cristã e da cultura clássica nas Américas portuguesa e espanhola. Assim, a administração e a intelectualidade europeia da época colonial no Brasil do século XVI estavam vinculadas a uma tradição erudita renascentista, relacionada também com o uso acadêmico e literário do Latim, de que um dos vultos foi José de Anchieta.

\section{O projeto missionário e a colonização linguística}

O Brasil Colônia surge como um projeto civilizatório no século XVI, sob o signo de uma sociedade multicultural, advinda do processo de navegaçóes transatlânticas e de "Descobrimentos" de rotas marítimas pelo oceano Atlântico, unindo a Europa às Américas, pela dominação territorial, e posteriormente as Américas à África, pela escravidão. Dessa forma, cumpre salientar que esse processo transatlântico intercultural se remetia à criação de uma colônia, que se configurava como a periferia de uma metrópole, situada no mercado do continente europeu, sob a égide da monarquia absolutista portuguesa e do papado, no caso do Brasil quinhentista. Por isso, este processo de globalização pelas navegaçóes é caracterizado sobretudo por uma relação entre metrópole e colônia, na fundação da América portuguesa, assim como ocorria com a América espanhola. 
Desde o ano de 1500, a chegada da esquadra de Cabral, em cujas velas se destacava o símbolo da Ordem de Cristo $^{4}$, descendente da tradição templária de Portugal, refletiria uma nova expansão da cristandade europeia, marcada pela primeira missa na Terra de Santa Cruz por Frei Henrique de Coimbra, franciscano, membro da Ordo Fratrum Minorum (FERREIRA, 2009, p. 873). Muitos dos europeus que migraram para o Brasil eram cristãos-novos, rechaçados por setores mais conservadores da Igreja Romana, que se fortaleciam com a criação de tribunais da Inquisição e do Santo Ofício em Portugal e Espanha.

Essa expansão globalizada, na América do século XVI, está patente em uma perspectiva de expansão de domínios dos reinos absolutistas europeus, tanto temporal, quanto espacialmente. $\mathrm{O}$ processo de globalização está tanto evidenciado na confecção do Mapa Mundi de Mercator em 1578, que viraria referência até as sociedades atuais, quanto pela adoção do Calendário Gregoriano em 1582, que serviria para datar desde então as sociedades integradas neste processo de globalização.

Sobre Mercator, cuja representação renascentista demonstra o eurocentrismo na projeção cilíndrica do globo:

$\mathrm{Na}$ Cartografia do Renascimento Científico, dois nomes foram da maior importância: o belga Abraão Ortelius (1527-1598), autor de Theatrum Orbis Terrarum (Aspectos das Terras do Globo), de 1570 , em que reuniu tudo quanto haviam escrito os seus contemporâneos sobre a Terra, representando um conjunto de cartas geográficas (projeção em forma de coração), consideradas o primeiro Atlas publicado; e Gerardus Mercator (1512-1594), também de Flandres, criador da projeção cilíndrica, autor de vários mapas (inclusive um mapa-múndi, em 1569, da França, Alemanha e Países Baixos em 1585; da Itália, Bálcãs e Grécia, em 1589); e da obra póstuma Atlas sive Cosmographiae Meditationes de Fabrica Mundi et Fabricati Figura (Atlas ou Meditaçóes Cosmográficas sobre a Formaçáo do Mundo e Seu Aspecto depois de Formado), de 1595, cuja palavra inicial, daí por

4 LEITE, 2016: "Os portugueses, assim, com as naus de Cabral carregando em suas velas o símbolo da Ordem de Cristo (que financiara a viagem), chegam no ano de 1500 às terras brasilis, delas tomando posse em nome de seu Rei, por direito de conquista, a que se arrogavam". 
diante, serviu para designar os conjuntos de mapas. Mercator publicou, em 1578, com correçóes e comentários, 27 mapas preparados por Ptolomeu (ROSA, 2012, p. 451).

Quanto ao calendário gregoriano, cuja concepção remete ao início da era cristã romana, foi adotado também na colonização do Brasil:

[...] pelo decreto de março de 1582, Gregório XIII determinou que o dia que se seguiria à festa de São Francisco (quarta-feira, 4 de outubro de 1582) seria a quinta-feira, 15 de outubro.

O Calendário Gregoriano foi adotado, na data fixada por Roma, pela Itália, Polônia, Portugal e Espanha; a França o adotaria em dezembro do mesmo ano, e a Alemanha católica, em 1583. Os Estados protestantes da Alemanha se opuseram ao Calendário papista, só vindo a adotá-lo em 1700. A Inglaterra o adotou legalmente em 1752, quando o 14 de setembro se seguiu ao dia 2 de setembro; a Inglaterra aproveitou esta modificação para estabelecer o início do ano em 1 de janeiro, em vez de 25 de março. A Igreja ortodoxa recusou-se a aceitar o Calendário Gregoriano, vindo a Rússia a adotá-lo somente em 1923 (ROSA, 2012, p. 435).

Das matrizes étnicas iniciais, que formariam os regna Brasillia, ou a América Portuguesa, os povos indígenas constituíam maioria, em uma miríade de etnias, das quais se destacam quatro grupamentos linguísticos principais: os Tupi, os Jê, os Aruaque e os Caribe (CÂMARA JÚNIOR, 1979, p. 147). No século XVI, o contato dos portugueses com o grupo Tupi da costa constitui o grupamento inicial do processo de colonização do Brasil. Já em relação à população negra da África, trazida cativa à América portuguesa, é oriunda, no século XVI, do chamado ciclo da Guiné da costa, como supracitado.

A escravidão e a servidão eram instituições já adotadas na Europa e na África havia muitos séculos, sendo a base de sociedades antigas como o Império Romano, instituídas na Idade Média tanto por cristãos, quanto por mouros. Nas Américas, a instituição da escravidão ganhou contornos étnicos racistas, primeiro na escravidão indígena, tanto na forma compulsória, pelas "guerras justas", quanto pela voluntária, e depois na escravidão africana, con- 
figurando-se como traço do desenvolvimento da sociedade colonial. Por outro lado, a miscigenação acarretou em uma transfiguração étnica desde princípios da colonização, fator este que tornaria uma mera colônia de exploração ultramarina em um novo povo, sendo elemento amalgamador de ruptura com o eurocentrismo inicial.

Neste contexto multicultural, orbitando por suas três matrizes étnicas, que se confrontavam em estratos sociais antagônicos e complementares, o Brasil Colônia do século XVI apresentaria, além do contexto multicultural, também um contexto pluriétnico, com grande diversidade linguística. Deve-se, pois, considerar que o processo de colonização do Brasil, iniciado no século XVI, ocorrera antes da secularização dos reinos europeus, e este fator inclui, além das questóes econômicas, um contexto cultural vinculado às atividades missionárias de catequese, relacionadas com a colonização não só como um empreendimento de exploração econômica, mas também como uma forma de expansão e de transplante da identidade cultural religiosa europeia aos trópicos. Neste aspecto, para se analisar a sociedade incipiente do Brasil Colônia, é necessário evidenciar a ação missionária como um dos meios de fixação no território e na criação de uma nova sociedade, sob o signo do sincretismo.

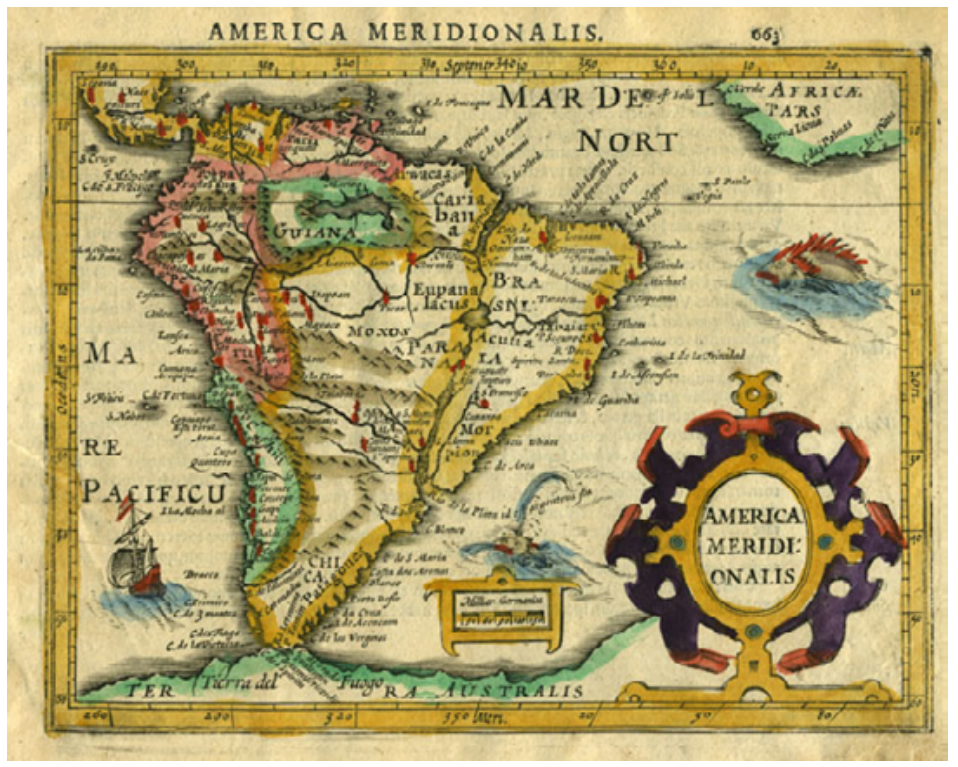

1. Imagem do mapa de Mercator da America Meridionalis 


\section{O latim no projeto missionário}

O uso do Latim no Brasil do século XVI contextualizava-se em dois aspectos, de um lado, na ação missionária para difusão da filosofia cristã católica, no arcabouço político do Concílio de Trento e da Contrarreforma, e, do outro lado, na política educacional do Humanismo renascentista, de cunho erasmiano, que caracterizou a reforma da Universidade de Coimbra e a política cultural empreendida por D. João III. Em relação à filosofia cristã oriunda da Reforma protestante, o principal evento nos trópicos, durante o século XVI, foi a participação de calvinistas franceses na tentativa de colonização da França Antártica, entre os anos de 1555 e 1567.

O Latim renascentista foi utilizado e ensinado no Brasil do século XVI como instrumento de integração à cultura eclesiástica e acadêmica europeia ultramarina, de tradição ibérica. Nos Colégios jesuíticos do Brasil, tanto as Divinae Litterae (Teologia) quanto as Humanae Litterae (Letras Clássicas) eram estudadas, sendo apenas o ensino de grego substituído pelo de Tupi. As atividades pedagógicas dos jesuítas desenvolveram-se sobretudo a partir do governo-geral de Mem de Sá, o terceiro a ocupar o cargo.

A fim de analisar e de exemplificar o uso do Latim no Humanismo renascentista, em Portugal e no Brasil do século XVI, segue uma leitura mais adiante de excerto da obra De Gestis Mendi de Saa de José de Anchieta, escrita no Brasil, mas editada em 1563 na tipografia de Coimbra. O contexto desta obra de Anchieta deriva de um movimento intercultural originado em Portugal, o Humanismo renascentista português, que influiu no estabelecimento da América portuguesa. Analisar esse movimento é fundamental, enquanto conhecimento de mundo, para a tradução e a interpretação da obra novilatina de Anchieta e para se evidenciar a tradição do ensino de Latim no contexto do século XVI.

\section{O real colégio das artes de coimbra}

Inspirado pelo Colégio Santa Bárbara em Paris, dirigido pelo humanista português Diogo de Gouveia, por cerca de vinte anos, D. João III fundou em Portugal o Real Colégio das Artes e Humanidades de Coimbra em 1542, que iniciou, formalmente, suas atividades no ano de 1548 . Fundado no contexto da educação renascentista e no ensino de Humanidades Clássicas, o Real Co- 
légio tinha como missão preparar jovens em Portugal para o acesso à Universidade de Coimbra, o que se constituiria como parte da política cultural do reinado de D. João III. José de Anchieta ainda adolescente fora aluno do Real Colégio das Artes de Coimbra.

A reforma da Universidade e a fundação do Real Colégio, em Coimbra, foram resultantes da política intercultural de bolseiros dos reis D. João II e D. Manuel, que fomentaram relaçóes com outras universidades, como a de Louvain, a de Toulouse e a de Paris, no momento em que Portugal estabelecia suas colônias ultramarinas e firmava sua identidade como ator geopolítico no continente. Dessa forma, pela fundação e pela reforma das instituiçóes de ensino em Portugal, a partir de intercâmbios com outros reinos europeus, sobretudo a França, D. João III conseguiu desenvolver, posteriormente, o Humanismo renascentista como uma política cultural, naquele momento histórico 5 .

Esse contexto de Portugal no século XVI teria como resultante um fluxo de humanistas que passariam a lecionar nas instituiçóes fundadas e reformadas por D. João III. Personalidades, oriundas do Colégio de Santa Bárbara em Paris e do Colégio de Guiena, como André de Gouveia, Elias Vinet, Nicolau Grouchy, Guilherme de Guérente, Antônio Mendes de Carvalho, João da Costa, Jorge e Patrick Buchanan, e Diogo de Teive, entre outros, seguiram a Portugal para constituir o corpo docente do Real Colégio, cabendo a direção a André de Gouveia, e este falecido, a João da Costa. Os humanistas Marcial

5 Após a reforma da Universidade de Coimbra e da fundação do Real Colégio das Artes, por intermédio de Diogo de Gouveia, os jesuítas chegariam a Portugal, cf. NASCIMENTO, 2000, p. 46-47: "É neste ambiente de suspeição científica, didáctica e religiosa, de falta de confiança institucional derivada ou concomitante com algum laxismo pedagógico, que os Jesuítas são acolhidos em Portugal. Haviam sido recomendados a D. João III em 1538 por Diogo de Gouveia, que dirigia o Colégio de Santa Bárbara em Paris. A primeira intenção do rei era captá-los para a evangelização das novas terras e para tanto fizera diligências através do embaixador português em Roma, em 1539, sob pretexto de os enviar à Índia. Uma vez chegados a Lisboa, em 1540, o soberano pretende que eles fiquem em Portugal, mas tem de enfrentar a oposiçáo de Francisco Xavier que apela para Inácio de Loiola. Este permite que Francisco Rodrigues aceda ao convite do rei, com a condição de lhe ser disponibilizado um Colégio em Coimbra, junto da Universidade, com o intuito de recrutar novos membros para a Companhia de Jesus. Num primeiro tempo, no entanto, o rei conserva-os em Lisboa, onde entrega à Companhia um edifício em que é instalada a Casa de Santo Antão". 
de Gouveia, Mestre Eusébio e Arnaldo Fabrício também participaram desse primeiro momento da história da instituiçãa ${ }^{6}$.

A educação no Real Colégio das Artes de Coimbra, no século XVI, era embasada no ensino do Latim, sobretudo. Através dos discursos conhecidos como Oraçóes de Sapiência, proferidos no Real Colégio de 1548 a 1555, são descritos os ideais do Humanismo renascentista como padrão educacional. $\mathrm{O}$ discurso de inauguração do Real Colégio proferido por Arnaldo Fabrício, aos dias 21 de fevereiro de 1548, intitulado De liberalium artium studio é uma profunda defesa da educação humanística clássica, fundamentada nas artes liberais, no trívio e no quadrívio e no estudo da res litteraria. Logo, o ensino de Latim, apreendido com base na leitura dos autores clássicos, seria o viés para o processo de ensino-aprendizagem posterior do Grego, do Hebraico, da Aritmética, da Música, da Geometria, da Astronomia, da Gramática, da Dialética e da Retórica, acrescendo-se, por fim, a Jurisprudência, a Medicina e a História. Nesse padrão de ensino, foi educado José de Anchieta, tendo chegado aos 14 anos de idade a Coimbra, no ano de inauguração do Real Colégio em $1548^{7}$.

D. João III alinhava-se incondicionalmente com Roma, o que gerava uma tensão no equilíbrio de poder com outros reinos, sobretudo França, refle-

6 A tradiçẫo de ensino das três línguas clássicas renascentistas, o grego, o latim e o hebraico, em Portugal, à época da fundação do Real Colégio das Artes, em 1548, estava de certa maneira vinculada à tradição francesa da época. Se, por um lado, as obras de Nicolau Clenardo influenciaram o estudo de hebraico e grego, como a Tabula in Grammaticam Hebraeam e Institutiones in Linguam Graecam, o ensino de Latim será voltado ao uso da obra Commentarii Gramatici de Johannes de Spauter, conhecido também como Despauterius, NAVARRO, 2000, p. 396 e passim: "Adotou-se a gramática de Despautério em Portugal, desde o início, nos colégios da Companhia de Jesus, e ainda continuava em uso quando Manuel Álvares publicou sua célebre gramática, isso em 1572."

7 MARTINS, 2000, p. 527-528: "O Colégio das Artes foi fundado pelo Rei D. João III, com a finalidade de dotar a Universidade de "Escolas Menores", onde os estudantes adquirissem, sobretudo, os conhecimentos de Latim e Filosofia com que se habilitassem a cursar, com proveito, qualquer das Faculdades Maiores de Teologia, Cânones, Leis ou Medicina. Segundo o Primeiro Regimento, de 16 de Novembro de 1547, devia ter aulas de Latim, Grego e Hebraico, Artes e Matemáticas, num total de 19 professores." Em seguida, Diogo de Teive, ao dia 1 de Outubro de 1556 entregaria, oficialmente, o Real Colégio das Artes de Coimbra ao Provincial da Companhia de Jesus, MARTINS, 2000, p. 528-529: "Conservando o título de "Colégio Real”, os Jesuítas aceitaram-no, isento da jurisdição da Universidade (embora dela fizesse parte, como membro) e com as aulas seguintes: 4 de Filosofia, 1 de Grego, 1 de Hebraico, 10 de Latim e 1 de Ler e Escrever que, mais tarde, seria substituída por outra de Latim”. 
tindo-se na colonização da América portuguesa. Em seguida, nesse contexto, José de Anchieta, ainda jovem, seria enviado ao Brasil em 1553, para atuar como missionário jesuíta no projeto de catequese do Nouus Mundus, a política de Conversão do Gentio ${ }^{8}$.

\section{Os aldeamentos na baía e o de gestis mendi de saa}

Inicia-se a fundação de vilas e aldeias na Bahia, oficialmente, durante o governo-geral do jurista Mem de Sá, cuja formação se vinculava à Universidade de Salamanca. O terceiro governador-geral tentaria estabelecer uma legislação comum a portugueses e aos povos indígenas, criando, a grosso modo, o Estado monista na América portuguesa como execução da política de colonização? Essa tentativa de resolução de conflitos inicial entre portugueses e indígenas no projeto colonial foi registrada por Anchieta no poema De Gestis Mendi de Saa de 1563. O poema de Anchieta narra os eventos que ocorreram antes da fundação das vilas até a fundação das primeiras missóes jesuíticas na Bahia.

De um lado, predominaria a perspectiva assimilacionista e escravista dos colonizadores em relação aos povos indígenas, de outro, os povos indígenas veem como invasores os colonos, enquanto lutam por resistir ao processo de assimilação ${ }^{10}$. Os conflitos interculturais são patentes no discurso que

8 VIOTTI, 1980, p. 33: “A 8 de Maio de 1553, embarcava em Lisboa rumo ao Brasil, na frota do Governador Duarte da Costa, o jovem escolástico da Companhia de Jesus, natural das Canárias, José de Anchieta”.

9 O Governo-geral, iniciado em 1548 com Tomé de Souza e sucedido por Duarte da Costa e por Mem de Sá, dará a primeira unidade ao Estado do Brasil. Com a implantação de uma Ouvidoria, de uma Provedoria, dos serviços espirituais, com o início da criação de gado, a imigração de degredados, lavradores e artesãos, a colonização litorânea se estabelece, alterando a dispersão administrativa das capitanias hereditárias. HOLANDA, 2007, p. 123-155.

10 Ainda que a Bula Veritas Ipsa de 1537 proibisse a escravidão indígena, os colonos, que habitavam apenas o litoral, da Bahia a São Vicente no século XVI, não aceitavam a integração com os povos autóctones. Pelo dispositivo jurídico da Guerra Justa (Mars iustus), equivalente à legítima defesa, puderam empreender contínuas guerras contra as aldeias indígenas. CAVALIERE, 2000, p. 1165: "Com efeito, ao longo do litoral brasileiro, havia grande diversidade étnica caracterizada por influência indígena, branca (majoritariamente portuguesa, mas em certas regióes também holandesa e francesa) e mesmo negra, conforme adverte Frederico Edelweiss, com base em informaçáo de Fernão Cardim: “(...) por 1585, já eram poucos os índios sobreviventes em volta de Pernambuco, enquanto para 
Anchieta reproduz, e que teria sido dirigido a Mem de Sá por colonos sobre os indígenas, vistos hiperbolicamente de forma negativa, sendo o costume da antropofagia argumento central utilizado por colonizadores para a imposição sobre os povos indígenas. Um fato marcante, em relação à antropofagia, teria sido a execução do Bispo Dom Pero Fernandes Sardinha em 1556, primeiro bispo do Brasil, devorado por indígenas Caetés. O bispado da Bahia havia sido fundado em 1551, tornando-se independente do bispado de Funchal, na Madeira.

Além da ação missionária da Societas Iesu no Brasil do século XVI, cuja ordem pontífice fora fundada no ano de 1534, com finalidade de levar o cristianismo aos confins do globo, outras ordens participaram do projeto de colonização da América Portuguesa, como os Franciscanos. Estes empreenderam uma missão no litoral de Santa Catarina, na localidade de Laguna, conhecida por Mbiaça, entre 1538 e 1548, com povoados carijós (COSTA, 2011, p. 1-2), a Ordo Fratrum Minorum ergueu conventos em Recife e Olinda em 1585, em Igaraçu em 1588, na Paraíba em 1589, e em Vitória em 1591. Já os Beneditinos ergueram mosteiros em Salvador em 1582, no Rio de Janeiro em 1590, tendo chegado a São Paulo em 1598. Os Carmelitas, por sua vez, ergueram conventos em Olinda em 1583, em Salvador em 1586, em Santos em 1589, no Rio de Janeiro em 1590, em Angra dos Reis em 1593, em São Paulo em 1594, o que marcava outro aspecto multicultural do projeto missionário.

Vejamos um excerto do poema De Gestis Mendi de Saa, de Anchieta, sobre a fundação de vilas na Bahia:

2.000 vizinhos havia perto de 2.000 escravos africanos". Verifica-se, pois, que o foco de atuação dos missionários na disseminação da doutrina católica, que impunha o uso e ensino da língua da terra, eram os aldeamentos em que o contato inicial já se consolidara, não as tribos retiradas para o interior. Ratificam a hipótese vários documentos do século XVII que fazem menção ao labor catequista apenas em comunidades litorâneas no século anterior, quando o contato populacional ainda náo havia desfigurado o quadro de etnias inicial. O Padre Luiz Vicêncio Mamiani, nesse sentido, assevera que a preocupaçáo dos jesuítas em levar a doutrina para o interior só se manifesta com maior interesse e ao que tudo indica sem eficácia após a progressiva diminuição das populaçóes indígenas no extenso litoral entre o Maranhão e a Bahia em face da mortalidade expressiva ou da definitiva incorporação à cultura imposta pelo branco". 
Iamque pius Dominum caeli, terraeque, marisque ${ }^{11}$

Mendus adorari cupiens, sanctumque per oras

Australes Christi uenerari nomen Iesu,

Brasilles saeuo degentes more ferarum

Legibus impositis statuit frenare, cruentos

Compescens morsus hominum, ingluuiemque uoracem

Non patiens ultra satiari sanguine, sanctum

Ne ius Naturae, superi lexque alma Parentis

Frangatur, crebro cum ignobile murmure uulgus

Colluuies hominum, quos uel malesuada cupido

Vel metus urgebat, iactabat talia passim:

"Quis nouos hic nobis praeses? Quo pristina scindit

Iura modo? Moresque nouos inducere tentat

Gentibus indomitis, uiuendi et tradere normam?

Hiccine amicitiae concordis foedera saeuis

Suadebit populis? Humanis desinat uti

Carnibus in pastum Brasillica natio, saeuas

Extirpans animis iras, diuturnaque bella?"

\section{Tradução}

E então, o piedoso Mem de Sá, desejoso de que o senhor do céu

Da terra e do mar fosse adorado, e o santo nome

De Jesus Cristo fosse venerado nos territórios do Sul,

Estabeleceu frear os habitantes do Brasil,

Que passavam a vida no feroz costume das feras, com a instituição de leis, A deter as mordidas sangrentas dos homens e seu estômago voraz,

Não permitindo mais se saciarem com sangue humano, para que

Não se rompesse o direito natural, e a mansa lei do Pai

Celeste, quando, com um grande murmúrio, o ignorante povoado de colonos,

Confusão entre os homens, aos quais urgia ora uma ambição mal-intencionada,

Ora o medo, lançava tais palavras por todos os lados:

11 Texto estabelecido pelo fac-símile da Edição 1563, ANCHIETA, 1997. 
"Que novo Governador temos? De que modo rescinde as antigas Leis? E tenta introduzir novos costumes aos povos Indômitos, até transmitir-lhes uma norma para viver? Por acaso, ele exortará tratados de aliança em boa harmonia Aos povos ferozes? Para que as naçóes brasílicas abandonem A carne humana para repasto, extirpando a ira selvagem Em seu espírito, e cessando as guerras antigas?

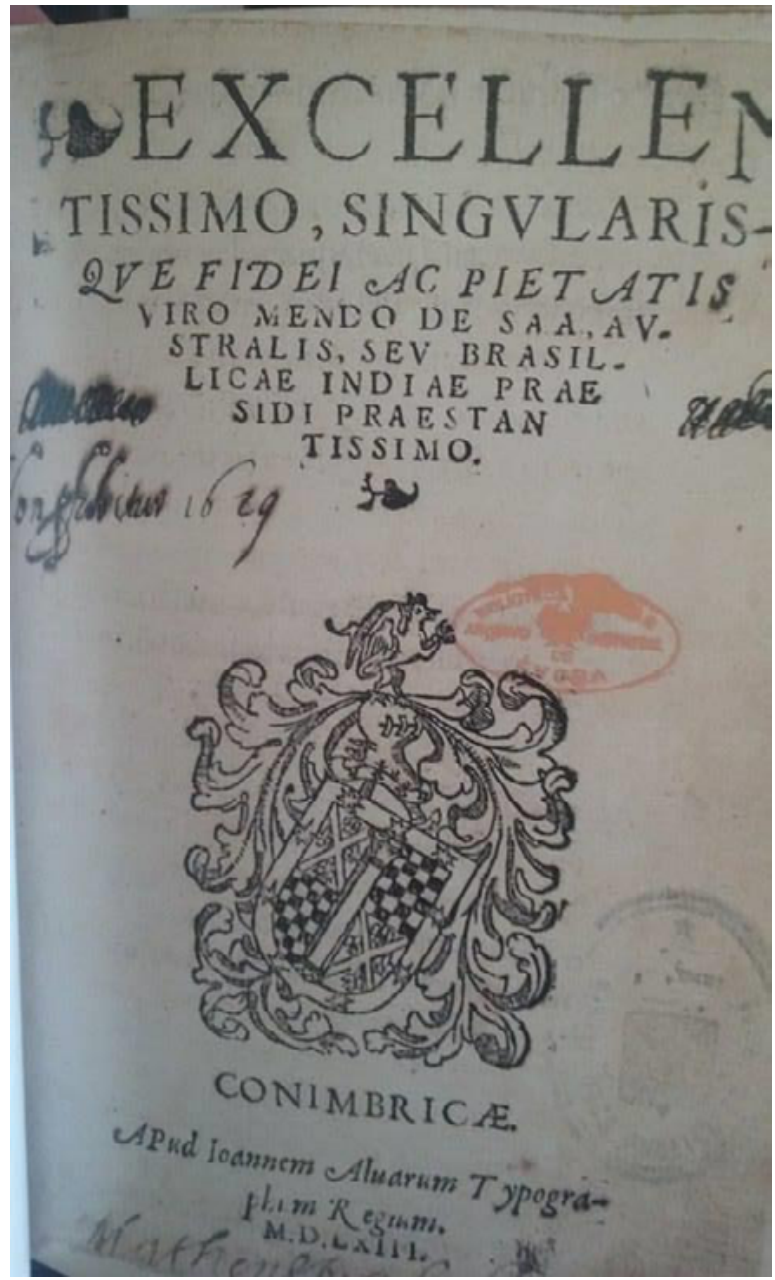

2. Frontispício da obra De Gestis Mendi de Saa de 1563, atribuída a José de Anchieta. 


\section{Os Colégios dos Jesuítas no Brasil}

Em 1549, o Collegio do Salvador da Bahia fora fundado pelo Pe. Manuel da Nóbrega, SJ (1517-1570), tendo como modelo institucional o Real Colégio das Artes e Humanidades de Coimbra. Faz-se notar, entretanto, uma diferença entre ambas as instituiçôes, se em Coimbra a fundação do Colégio fora desenvolvida para servir ao reino, na Bahia, e nas demais capitanias e regióes da América portuguesa, a criação dos Colégios é classificada como missão, tendo por objetivo a formação de padres para a catequese.

Dessa forma, ainda que o estudo de filosofia e de literatura clássica seja semelhante em seus aspectos fundamentais, as motivaçóes e o contexto cultural da educação humanística diferem na relação entre metrópole e colônia. Em Coimbra, o Real Colégio formava quadros para o ingresso na Universidade de Coimbra e para a administração do reino, já na Bahia, o Collegio do Salvador preparava padres para atuarem como missionários na colônia, a fim de expandir a possessão de terras.

Por influência do Humanismo renascentista, no Collegio do Salvador da Bahia era ensinado o Latim e os elementa, a ler e a escrever. Além disso, o colégio passaria a ter subsídio real para o sustento dos padres, o que lhe daria o título de Real Colégio, proporcionando ensino público e instrução gratuita ${ }^{12}$.

12 FRANZEN, 2000, p. 222-224: "Os Colégios eram centro de cultura e de piedade, de doutrina e de assistência: na Praça, nos Hospitais, na Botica do Colégio, na Cadeia e na Igreja, com suas Congregaçóes, Sacramentos, Jubileus e Festas. Estes eram os ministérios diários. Todos eram utilizados com os mesmos objetivos: a catequização do gentio, a moralização dos colonos e a assistência material e espiritual aos necessitados de ajuda. Os colégios eram criados a partir de ordem expressa do Rei com dotação real - eram os Reais Colégios - ou com autorização real, mas com doações de particulares, que recebiam o título de "fundador”. No Brasil, eram três os colégios que recebiam dotação real e possuíam o título de Real Colégio: o da Bahia, o do Rio de Janeiro e o de Pernambuco. (...) Em 1556, o Colégio dos Meninos de Jesus foi elevado a colégio canônico, com o nome de Colégio de Jesus. A escola de ler e escrever progredira bastante. A alguns alunos era ensinada a "gramática", isto é, o latim. O colégio passara de elementar para secundário. A instituição cresceu; em 1568, já havia uma sala de aula grande para os cursos de Casos e Latinidade. O Padre Inácio Tolosa, quando Provincial (1572-1577), deu início às obras do novo prédio, que somente foi inaugurado em 1591. Mas, já em 1585, escrevia Fernáo Cardim que o colégio possuía uma boa capela, livraria e "alguns trinta cubículos; os mais deles têm as janelas para o mar". No Brasil, segundo Serafim Leite, nos colégios devia haver aulas de ensino secundário, pelo menos 
De certa maneira, o insucesso da catequese, a partir das relaçóes interculturais baseadas no ensino e na educação humanística, abriria espaço para o uso da violência, na medida em que os missionários cediam lugar a soldados e colonos interessados na posse da terra e de escravos, o que redundaria em conflitos contínuos, antes do estabelecimento das primeiras vilas ${ }^{13}$.

Entre o material didático utilizado na época, encontravam-se textos de humanistas e de autores clássicos, seguindo, dentro de suas limitaçóes, o padrão educacional adotado em Coimbra. A estes se acrescentariam os Cursus Collegi Conimbricensis, editados a partir de 1591, sobre a filosofia aristotélica, que compunha o ensino de Artes, por exemplo.

Já o ensino de Humanidades inicial era composto pelo estudo das $\mathrm{Hu}$ maniores Litterae, da Literatura Latina, tendo primazia o estudo de Vergílio, Cícero e Ovídio, como em Coimbra. A respeito da metodologia de ensino do Latim empregada na época do Renascimento, pode-se afirmar que uma disputa pedagógica entre ratio e usus era tópico central no ensino de Latim.

Gramática ou Humanidades. O estudo do latim era considerado fundamental na época. No Colégio da Bahia, os exercícios escolares eram escritos em latim, nas aulas falava-se latim. O português só era permitido durante o recreio e nos dias feriados. A língua indígena cedo foi a grande preocupação dos padres que procuravam dominá-la, a fim de melhor se comunicarem com os nativos. Desde o momento em que chegou em São Vicente, José de Anchieta preocupou-se em estudar a língua dos índios, escrevendo sua primeira gramática: Arte da gramática da língua mais usada na costa do Brasil. Desde 1555, em forma de manuscritos, o livro era utilizado em Piratininga. E, em 1560, o Padre Luis da Grã ordenou que fosse utilizado no Colégio da Bahia, onde a língua dos índios passou a ser ensinada. No curso de Letras Humanas estudavam-se todos os clássicos, especialmente Virgílio e Cícero, recomendados pela Ratio Studiorum. Os estudos de Lógica, Física, Metafísica, Ética e Matemática faziam parte do Curso de Artes ou Ciências Naturais. Em 1572, iniciava-se o curso de Dialética e Teologia, o qual se subdividia em: Moral e Especulativa."

13 A fundação do Governo-geral, como política de unificação da América portuguesa, com sede na Bahia, por D. João III, permitiu uma política de ocupação territorial, numa época em que Portugal perdia para os mouros suas possessóes na África. Coube a Tomé de Souza, em 1549, homem de armas, combatente que lutara em Arzila e Safim, a função de Governador-Geral, incialmente, cargo de mandato trienal, tendo sido sucedido por Duarte da Costa e este pelo jurista Mem de Sá. Fausto (2006, p. 20): "A instituição do governo-geral iria representar um passo importante na reorganização administrativa da colônia. Tomé de Souza - um fidalgo com experiência na África e na Índia - chegou à Bahia acompanhado de mais de mil pessoas." 
José de Anchieta teria sido, por um breve período, estudante do Real Colégio da Bahia, dando continuidade à sua formação no Real Colégio das Artes de Coimbra, sendo ordenado padre no ano de $1566^{14}$.

José de Anchieta, como noviço, esteve presente na fundação do Colégio de São Paulo de Piratininga, aos dias 25 de janeiro de 1554. Considera-se a fundação do Colégio de São Paulo de Piratininga como a fundação da atual cidade de São Paulo, tendo em vista esta ter sido a sua primeira construção, ao mesmo tempo em que marca o início da missão jesuítica que se estabelecia na região sul do Brasil, na antiga Capitania de São Vicente ${ }^{15}$.

Há um resquício da educação humanística, no padrão do Humanismo renascentista português, mesmo sob a égide da catequese missionária e da política colonial portuguesa, no Brasil quinhentista. Esse padrão educacional firmar-se-ia a partir de 1599, com a Ratio Studiorum, que oficializa práticas educacionais que já estavam vigentes desde a reforma do Real Colégio das Artes de Coimbra, em 1548, por D. João III, e passaria a ser adotada nas instituiçôes jesuíticas, às quais inspirou ${ }^{16}$.

14 SILVA (2000, p. 1000-1001): “Como se sabe, a vida do Padre José de Anchieta compreende três etapas sucessivas: a dos 14 anos iniciais - 1534/1548 - passados em sua terra natal, em Tenerife (Ilhas Canárias); a dos cinco anos seguintes - 1548/1553 - na cidade de Coimbra; e por fim os 44 anos vividos no Brasil - 1553/1597, em permanente desempenho da ação missionária a que se devotou incansavelmente, sem nunca ter regressado à Europa. Essas circunstâncias fizeram dele um patrimônio dos três países em que viveu e a que está ligado por fortes vínculos. Foi no Brasil que exerceu o notável papel de aglutinador dos elementos da cultura espanhola, da cultura portuguesa, da cultura brasileira e das culturas indígenas, dos quais adquirira fundados conhecimentos, deles se utilizando na composição da sua obra literária”.

15 A Arte de Gramática da Lingua mais usada na Costa do Brasil, obra gramatical de José de Anchieta, publicada em Portugal em 1595, que descreve o Tupi antigo, é uma das resultantes da política colonial de conversão. BECHARA (2000, p. 512): "Para cumprir uma das regras da Companhia de Jesus, que é a de que todos os seus integrantes devem aprender a língua da terra onde residem, se não virem que é mais útil a materna ou o latim, desde cedo, nos dois principais campos de ação dos jesuítas - a Capitania de S. Vicente e a da Bahia - iniciou-se a pregação na língua indígena, especialmente em $\mathrm{S}$. Vicente, porque aí moravam muitos portugueses que já falavam a língua da costa e, ao se agregarem à Companhia, foram muito úteis nessa atividade religiosa”.

16 O conjunto de normas educacionais intitulado Ratio atque Institutio Studiorum, publicado em 1599, pelos jesuítas, é um documento que foi construído pela experiência docente e 
Em 1567, é fundado no Rio de Janeiro o Colégio dos Jesuítas no Morro do Castelo. Na cidade, que havia sido fundada em 1565, no contexto da expulsão dos franceses da Baía de Guanabara, iniciou-se o curso de Humanidades como nos outros estabelecimentos da América portuguesa, constituindo-se de aulas de Latim, Gramática, Retórica e leitura de autores clássicos.

O ensino e o uso do Latim no Brasil quinhentista são participantes do processo de colonização linguística, iniciada com a criação das primeiras instituiçôes administrativas da colônia pela metrópole. Com o estabelecimento do projeto colonial, toda a comunidade linguística multicultural dos regna Brasillia do século XVI seria considerada súdita da monarquia absolutista de Portugal e, por vias desta, subordinados a Roma e ao papado, cujos agentes principais neste momento histórico foram os jesuítas. O Tratado de Tordesilhas limitaria até 1580 os limites do Brasil Colônia na costa litorânea.

\section{Referências}

ANCHIETA, José de. De Gestis Mendi de Saa, poema epicum. Original acompanhado de introdução, tradução e notas pelo Pe. Armando Cardoso, S.I. São Paulo: Loyola, 1970.

. De Gestis Mendi de Saa. Edição fac-similar. Rio de Janeiro: Fundação Biblioteca Nacional, 1997.

AZEVEDO FILHO, Leodegário A. de. Anchieta e a Literatura Barroca em Latim. Letras. Número 35: 37-47, Curitiba: UFPR, 1986.

BECHARA, Evanildo. Sobre influências das ideias linguísticas na Arte de Gramática de Anchieta. Actas do Congresso Internacional Anchieta em Coimbra - Colégio das Artes da Universidade (1548-1998). V. 2: 511-524, Coimbra: Fundação Eng. António de Almeida, 2000.

BICALHO, Maria F. B. A França Antártica, o corso, a conquista e a "peçonha luterana”. História, 27 (1): 29 - 50, 2008.

discente na época da Renascença, referente, sobretudo às experiências vividas em Portugal, durante meados do século XVI. Esse documento sintetiza o Humanismo cristão como padrão pedagógico a ser utilizado nas missóes ultramarinas. LEITE (1938, p.72): “Depois do estudo elementar, que também houve sempre nos Colégios do Brasil, o primeiro curso segundo S. Inácio, abrangia as Letras Humanas, o latim, o grego e o hebreu. Entendia ele por Letras Humanas, além da Gramática, a Retórica, a Poesia e a História”. 
BORTOLANZA, João. Mitologia Pagã em De Gestis Mendi de Saa. Actas do Congresso Internacional Anchieta em Coimbra - Colégio das Artes da Universidade (1548-1998). V. 2: 629-638, Coimbra: Fundação Eng. António de Almeida, 2000.

CÂMARA JÚNIOR, Joaquim Mattoso. Introdução às linguas indigenas brasileiras. Rio de Janeiro: Ao Livro Técnico, 1979.

CAVALIERE, Ricardo. A língua descrita por Anchieta na "Arte de Gramática da Língua mais Usada na Costa do Brasil". Actas do Congresso Internacional Anchieta em Coimbra - Colégio das Artes da Universidade (1548-1998). V. 3: 1161-1168, Coimbra: Fundação Eng. António de Almeida, 2000.

COSTA, Carlos Alberto Santos. A Sé primacial do Brasil: uma perspectiva histórico-arqueológica. Revista de História da Arte e Arqueologia, 15: 51-82, Campinas, 2011.

COSTA, Sandro Roberto da. O protagonismo dos franciscanos na evangelização no Brasil antes dos jesuítas: a experiência de Laguna. Revista de Investigación en Ciencias Sociales y Humanidades, 13: 1-14, Hidalgo, 2011.

DIAS, José S. da S. A política cultural da época de D. João III. Coimbra: Faculdade de Letras, 1969.

FAUSTO, Bóris. História concisa do Brasil. São Paulo: EdUsp, 2006.

FERREIRA, Paula Ruas \& al. Principais fatos da história franciscana e as açóes dos capuchinhos no Brasil e na Bahia. Anais do VIII Colóquio do Museu Pedagógico, p. 867-887, Vitória da Conquista, 2009.

FRANZEN, Beatriz V. Anchieta e a ação missionária dos colégios jesuíticos no Brasil - século XVI. Actas do Congresso Internacional Anchieta em Coimbra-Colégio das Artes da Universidade (1548-1998). V.1: 221-232, Coimbra: Fundação Eng. António de Almeida, 2000.

HOLANDA, Sérgio B. de. A época colonial. Rio de Janeiro: Betrand Brasil, 2007. V. 1.

KALTNER, Leonardo F. Brasil e Renascença: a cultura clássica na origem do Brasil. Curitiba: Appris, 2011.

KOCH, Ingedore G. V. Introdução à Linguística Textual. São Paulo: Martins Fontes, 2009.

LEITE, José Luís Marasco. A apropriação das terras brasileiras. Anotações preliminares, http://egov.ufsc.br/portal/sites/default/files/anexos/9772-97711-PB.pdf. Acesso em 12/04/2016. 
LEITE, Serafim. História da Companhia de Jesus no Brasil. Rio de Janeiro: Civilização Brasileira, 1938. V.1.

MANACORDA, Mário Alighiero. História da Educação. Tradução de Gaetano Lo Monaco. São Paulo: Cortez, 2006.

MARIANI, Bethânia. Políticas de colonização linguística. Letras: Revista do Programa de Pós-Graduação em Letras da Universidade Federal de Santa Maria, 27: 73-82, Santa Maria, 2003.

MARTINS, Fausto S. Vicissitudes da construção do Colégio das Artes. Actas do Congresso Internacional Anchieta em Coimbra - Colégio das Artes da Universidade (1548-1998). V. 2: 525-538, Coimbra: Fundação Eng. António de Almeida, 2000.

MOURA, Clóvis. Dicionário da escravidão Negra no Brasil. São Paulo: EdUsp, 2004.

NASCIMENTO, Aires A. Laudes Studiorum: o humanismo jesuítico dos primórdios (no cenário de Anchieta e da Ratio Studiorum). Actas do Congresso Internacional Anchieta em Coimbra - Colégio das Artes da Universidade (15481998). V. 1: 39-64, Coimbra: Fundação Eng. António de Almeida, 2000.

NAVARRO, Eduardo de A. O ensino da gramática latina, grega e hebraica no Colégio das Artes de Coimbra no tempo de Anchieta. Actas do Congresso Internacional Anchieta em Coimbra - Colégio das Artes da Universidade (15481998). V.1: 385-406, Coimbra: Fundação Eng. António de Almeida, 2000.

NÓBREGA, Manuel da. Cartas do Brasil e mais escritos (Opera Omnia). Introdução, notas históricas e críticas de Serafim Leite. Belo Horizonte: Itatiaia, 2000.

PINHO, Sebastião Tavares de. Humanismo em Portugal. Lisboa: Imprensa Nacional-Casa da Moeda, 2006. 2 v.

OGOT, Bethwell Allan (org.). História geral da África, $V$. África do século XVI ao XVIII. Brasília: UNESCO, 2010.

OLIVEIRA, Maria Inês Côrtes de. Quem eram os "negros da Guiné? A origem dos africanos na Bahia. Afroasia, 19-20: 37-73, Salvador, 1997.

RAMALHO, Américo da Costa. Os Versos Latinos de Francisco de Sá e a autoria do poema De Gestis Mendi de Saa. Humanitas. Volume LI: 241-250. Coimbra: Universidade de Coimbra, 1999.

REES, Fran. Johannes Gutenberg. Minneapolis: Compass Book Points, 2005.

RIBEIRO, Darcy. O povo brasileiro. São Paulo: Companhia das Letras, 2003. 
ROSA, Carlos Augusto de Proença. História da ciência: da antiguidade ao renascimento científico. Brasília: FUNAG, 2012.

SILVA, Maximiano de Carvalho. José de Anchieta: uno e múltiplo. O missionário e os vários desdobramentos das suas atividades evangelizadoras em terras do Brasil (1553 a 1597). Actas do Congresso Internacional Anchieta em Coimbra - Colégio das Artes da Universidade (1548-1998). V.3: 999-1016, Coimbra: Fundação Eng. António de Almeida, 2000.

TANNUS, Carlos A. K. Um olhar sobre a literatura novilatina em Portugal. Calíope, Presença Clássica, 16: 13-31, Rio de Janeiro, 2007.

VIOTTI, Hélio A. Anchieta, o Apóstolo do Brasil. São Paulo: Loyola, 1980.

\section{LATIN IN COLONIZATION OF SIXTEENTH CENTURY BRAZIL}

ABSTRACT: In this article, I analyze the history and the use of Latin in teaching in the Portuguese Renaissance Humanism and its influence in Sixteenth century Brazil, as an instrument of linguistic colonization for Portuguese America. For this analysis, I selected an excerpt from the neo-latin work De Gestis Mendi de Saa (On the deeds of Mem de Sa), written in Brazil by the Jesuit missionary José de Anchieta.

KEYWORDS: Cultural Studies; Linguistic Colonization; Latin America.

Recebido em: 13/04/2016 Aprovado em: 09/11/2016 